\title{
Zimbabwe's Experience in International Peace-Support Operations Since 1980
}

\author{
John Max Chinyanganya \\ National Defence College \\ University of Zimbabwe \\ Zimbabwe \\ Sadiki Maeresera \\ School of Social Sciences \\ University of KwaZulu-Natal, South Africa
}

\begin{abstract}
This article makes a critical analysis of Zimbabwe's contribution to peacekeeping and peacesupport operations in the period 1980 to 2000. It argues that this contribution has brought in a new thrust of peacekeeping operations of coercing the other party to the negotiating table. The article demonstrates the complexity of traditional peacekeeping operations where member states (and in this case Zimbabwe) have made notable contribution to the cause of peacekeeping operations, not only through traditional methods and principles of peacekeeping but also through various other methodologies such as peace-support efforts. Using the 1980 to 2000 time frame, in case studying Zimbabwe's contribution to peace support operations, this article demonstrates that even developing countries have the capacity and political willingness to shape international activities.
\end{abstract}

Keywords: Zimbabwe, United Nations, Peacekeeping/Peace Support Operations, NonMilitary Agencies.

\section{Introduction}

While peacekeeping operations are a crucial instrument at the disposal of the international community to advance peace and security, they are not clearly articulated or envisaged in the United Nations Charter. Chapter 1 of the United Nations Charter spelt out that one of the purposes and principles are; 'to maintain international peace and security and to that end to take effective collective measures for the prevention and removal of threats to the peace, and for the suppression of acts of aggression or other breaches of the peace and for the suppression of acts of aggression'. ${ }^{1}$ The Charter emphasizes that the purpose of the international governmental organization Is 'to develop friendly relations among nations based on respect for the principle of equal rights and self-determination of peoples, and to take other appropriate measures to strengthen universal peace among other purposes. ${ }^{2}$

Equally important for the purpose of the discussion is that the Charter established procedures for international action to deal with conflict between states. It distinguished between the 
'Pacific Settlement of Disputes' Chapter (VI) and 'Action with Respect to Threats to the Peace, Breaches of the Peace and Acts of Aggression' Chapter (V11), which could involve coercion including, in the last resort, the use of armed force.

United Nations pioneered peacekeeping operations in 1948 with the establishment of the United Nations Supervision Organization (UNTSO), a group of unarmed military observers that was sent to Palestine after the Security Council had obtained a truce there. Since its launch or establishment United Nations peacekeeping operations have remained a crucial instrument at the disposal of the international community to advance peace and security. The first armed peacekeeping operation was the United Nations Emergency Force (UNEF1) which was deployed in 1956 to 'secure and supervise' the cessation of hostilities following the Anglo-French-Israeli invasion of Egypt.

Since 1948, well over 750,000 military, police and civilian personnel from nearly 130 countries have served in peacekeeping operations in different parts of the world. Of these 1,910 lost their lives in the line of duty (as of June 2010). ${ }^{3}$

Conflicts today are a complex mix. Their roots may be essentially internal, but they are complicated by cross-border involvement, either by states or economic interests and other non-state actors. The former British Under-Secretary in charge of Peacekeeping Operations, Marrack Goulding argues that, over the years however, peacekeeping operations have evolved in their nature and modus operandi from the traditional peacekeeping to preventive peacekeeping; multinational peacekeeping and complex emergency peacekeeping. ${ }^{4}$ United Nations peacekeeping operations because of their universality, offer unique advantages as a means to address conflicts in the international system.

\section{The Meaning of Peacekeeping Operations in the International System}

Another term of interest in this discussion is peace enforcement. Under Chapter VII of the Charter, the Security Council can take enforcement measures to maintain or restore international peace and security. Such measures range from economic sanctions to international military action. ${ }^{5}$

When peacemaking efforts fail, stronger action by member states may be authorized under Chapter VII of the Charter. The Security Council over the years has authorized coalitions of member states to use "all necessary means" including military action, to deal with a conflictas it did to restore the sovereignty of Kuwait after its invasion by Iraq (1991); to establish a secure environment for humanitarian relief operations in Somali (1992); to contribute to the protection of civilians at risk in Rwanda (1994); to restore the democratically elected government in Haiti (1994); to protect humanitarian operations in Albania (1997); and to restore peace and security in east Timor (1999 and 2006). ${ }^{6}$ World leaders have also adopted the responsibility to protect principle which states that each individual state had the 'responsibility to protect' its population from genocide, war crimes, ethnic cleansing 
and crimes against humanity. When states are unable or unwilling to do so, or when they deliberately terrorise their citizens, the Westphalian principle of non-intervention yields to the international 'responsibility to protect. The United Nations subsequently adopted the United Nations Security Resolution (UNSC 1973) in 2011 which sanctioned the NATO attack on Libya on the pretext of 'responsibility to protect'. These actions, though sanctioned by the Security Council, were entirely under the control of the participating states. These were not United Nations peacekeeping operations which are established by the Security Council and directed by the United Nations Secretary General. ${ }^{7}$ Nonetheless, the implications of UNSC 1973 as well as other humanitarian interventions in Somalia and Kosovo are that international norms are shifting from sovereignty towards human security.

Peacekeeping forces have generally been unable to make peace, only to keep it. Joshua Goldstein and Jon C Pevehouse argue that to go into a shooting war and suppressing hostilities require military forces beyond those of past United Nations peacekeeping missions. ${ }^{8}$ Thus, peacekeepers are usually not sent until a cease-fire has been arranged, has taken effect, and has held up for some time. Wars may simmer along for years, taking a terrible toll, before the United Nations gets its chance.

To address the problem of finding a corrective measure of containing the vagaries of war before the involvement of the United Nations, the Secretary-General in 1992 proposed the creation of United Nations peace-making units that would not only monitor a cease-fire but enforce it if it broke down. ${ }^{9}$ The Secretary-General called for member states to make available, on a rapid deployment basis, 1000 soldiers each - especially trained volunteers - to create a standby United Nations army that could respond quickly to crises. However, not only did the member states refuse the request for soldiers, they even short down the idea of peacemaking altogether. ${ }^{10}$ Since then, the United Nations has authorized member states to provide real military forces, not peacekeepers, when fighting may be required. In an exception that may or may not indicate a trend, the Security Council broadened the mandate of the United Nations peacekeepers in Democratic Republic of Congo to let them protect civilians in 2013. ${ }^{11}$ Earlier in 2005, Pakistan peacekeepers killed 50 militia fighters after nine peacekeepers from Bangladesh were killed in an ambush. ${ }^{12}$

Meanwhile, the British Military Field Manual has defined peacekeeping as:

Operations carried out with the consent of the belligerent parties in support of efforts to achieve or maintain peace in order to promote security and sustain life in areas of potential or actual conflict..."13

Peace enforcement is defined by the same British Military Army Manual cited above as, "Operations carried out to restore peace between belligerent parties who do not all consent to intervention and who may be engaged in combat activities". ${ }^{14}$ Peace enforcement is therefore, arguably a conflict termination activity using direct or indirect intervention. Under Chapter V11 of the Charter, the Security Council can take enforcement measures to maintain or restore international peace and security. From a regional arrangement perspective, Article 
52 of the Charter states that, "nothing in the present Charter precludes the existence of regional arrangement or agencies for dealing with such matters relating to the maintenance of international peace and security as are appropriate for regional action... ${ }^{15}$ The former United Nations Secretary-General Boutros-Boutros Ghali gave impetus to the doctrine of regional arrangements through his treatise Supplement to an Agenda for Peace of January 1992. ${ }^{16}$

More precisely however, at the end of the twentieth century un-hitherto continental bodies began to partake in active peacekeeping commitments under the auspices of the United Nations. After the African Union's (AU) creation in 2002 from the Organization of African Union (OAU) in Durban, the Heads of Government and States adopted a protocol on the establishment of the Peace and Security Council where all member states indicated that they were committed to take concrete steps for peace and security as a viable precursor to development and economic prosperity in Africa. ${ }^{17}$ Two major components of the peace and security protocol emphasized the need to create the African Standby Force (ASF) and the Military Staff Committee (MSC) a continental early warning system meant to come to fruition by the end of 2005 .

Efforts to build African capacity to manage all aspects of conflict were designed to focus on the means necessary to strengthen existing and sub-regional institutions. There are four key areas which were identified as areas of priority, which needed to be addressed; prevention, management and resolution of conflict; peacekeeping and, peace enforcement; post-conflict reconciliation, rehabilitation and reconstruction; combating the illicit trafficking of small arms, light weapons and landmines. ${ }^{18}$

Meanwhile, at Kananakis (Canada) in 2002, the Group of Eight (G8) leaders adopted an Africa Action Plan (AAP) in response to the New Partnership for Africa's Development (NEPAD) initiatives in peace support operations and conflict prevention and management. ${ }^{19}$ In essence the AAP sets out how each of the G8 partners, together or individually, will enhance their engagement with African countries in support of NEPAD.

\section{Response to Peacekeeping Operations: The African Stand by Force Arrangements}

In preparation for the Maputo Summit in July 2003, African Chiefs of Defense Staff at their third meeting on May $15^{\text {th }}-16^{\text {th }}$ in Addis Ababa considered the operationalization of the Peace and Security Protocol. ${ }^{20}$ They adopted a policy framework for the establishment of the African Standby Force and Military Staff Committee. In particular, the policy framework provides for the establishment of an AU strategic level management capability that would enable the AU to undertake complex peace support operations in a phased approach by 2010. For practical purposes the AU and indeed the African sub-regional organizations can be commended for their role in the active mobilization of peacekeepers- a role that often comes at a great cost. In September 2007, ten (10) AU peacekeepers were killed in Sudan region, following an attack on their base by armed gunmen. 


\section{Zimbabwe's Experience in Peacekeeping and Enforcement Operations in the Cold War Era}

From its attainment of independence in April 1980, it is argued that Zimbabwe began to explore new avenues of reshaping the conventional discourse of peacekeeping as envisaged by the United Nations Charter in 1945.

The Unilateral Declaration of Independence (UDI) from Britain by the white minority government of Ian Douglas Smith ushered in a fifteen year bloody guerrilla war pitting the two liberation armies of the Zimbabwe African National Liberation army (ZANLA) and the Zimbabwe People's Revolutionary Army (ZIPRA) against the Rhodesian Security Forces (RSF). ${ }^{21}$ The protracted war had already claimed an estimated figure of over 30 000 causalities. ${ }^{22}$ Despite the imposition of international sanctions on Rhodesia in 1972 as an international community expression of their abhorrence on the country's apartheid system, the independence of Zimbabwe in April 1980 was born out of the Lancaster House Conference of September to December 1979. ${ }^{23}$ One of the most controversial issues, which were addressed at the Lancaster House Conference, was the cease-fire agreement that called for all warring parties to lay down their arms for peace. ${ }^{24}$ At the Lancaster House Conference, Britain called for a transition period which was to precede the first general elections based on universal suffrage in Rhodesia.

The cease-fire arrangements were to be monitored by a Commonwealth Monitoring Force (CMF) of several hundred troops from white Commonwealth countries and a compromise on the contributing countries for lack of African troops was eventually struck with the inclusion of troops from Kenya and Fiji. ${ }^{25}$ The elections duly held under the supervision of the Commonwealth Monitoring Force (CMF) resulted in the independence of the country in April 1980. When the CMF terminated its mandate in March 1980, a total of 1548 men and women had been deployed as part of the ceasefire monitoring group. ${ }^{26}$

Certain prerequisites for the success of launching peacekeeping/enforcement operations were beginning to emerge. These included a genuine desire on the part of opposing forces to resolve their differences peacefully, a clear mandate, strong political support by the international community, and the provision of the financial and human resources necessary to achieve the operation's objectives through the Commonwealth countries. The spirit and significance of peacekeeping as a mechanism of resolving conflicts was henceforth entrenched especially in the military establishment in the new Zimbabwe. While there was no precise authorization by the Security Council for the deployment of the Commonwealth countries, there was consent by the Rhodesian government and the two nationalist organizations to the deployment of the peacekeepers.

The peacekeeping/enforcement operation involved the deployment of military and police personnel, together with civilian staff. The military monitors were made up of unarmed officers typically to monitor the ceasefire. Lastly, the officers and soldiers in the monitoring 
mission had weapons, but these were for self-defense purposes only. ${ }^{27}$ The Commonwealth Monitoring Force thus successfully implemented the ceasefire agreement between the two liberation guerrilla forces and the Rhodesian Security Forces resulting in the elections of 1980 marking a new epoch in the discourse of peacekeeping at the height of the Cold War period.

No sooner than the country was celebrating its political independence when it was called to assist Mozambique a neighboring state which was on the verge of total collapse through the rebel attacks by Renamo or the Movement for National Resistance (MNR). According to Knox Chitiyo and Martin Rupiya, Renamo was originally sponsored by the Rhodesian Central Intelligence Organization (CIO) which emerged after 1974 as a spoiler to ZANLA rear bases security in Mozambique. The subsequent inheritance of Renamo by the South African Defense Force (SADF) soon witnessed an expanding war on Zimbabwe's borders early in its independence. The new Zimbabwean government was invited to support the Mozambique Armed Forces to repel the rebel MNR movement at the beginning of $1982 .{ }^{28}$ After more than ten years of sustained support to its neighbour, in 1992 the government of Mozambique and the MNR signed a peace agreement to end a long and debilitating civil war.

Meanwhile, efforts were intensified by the then apartheid regime to destabilize the neighbouring countries for over a decade and half under what was known as "Total National Strategy" by South Africa. ${ }^{29}$ For a period of over ten years the Zimbabwe Defense Forces (ZDF) deployed on what some scholars want to refer to as peacemaking operations in Mozambique. The military operation in the Mozambique campaign was a Front Line States (FLS) initiative designed to assist a fellow member state in a crisis. During the campaign, the Tanzania Defence Forces (TPDF) was briefly deployed along the north-eastern part of Mozambique against the MNR in support of the Mozambican government. Botswana provided among other contributions logistical support in terms of combat ammunition and general transport vehicles for the effort, while Zambia contributed in the diplomatic package to condemn the apartheid acts of atrocities against its neighbours.

As part of the 1992 agreement, the United Nations Peacekeeping Operation in Mozambique, deployed in 1993, successfully monitored the ceasefire, the demobilization of forces and the country's multiparty elections, held in 1994. Zimbabwe's 13 year involvement in the Mozambique war had proved a valuable conventional battle field experience throughout the army and air force as almost all units had been rotated during that period.

\section{The Mozambican Intervention from a Comparative Perspective}

During the Mozambique campaign the Front Line States (FLS), equally gained experience in mounting 'limited' joint operations in support of a regional neighbouring country. Not much has been written on the role of the Front Line States in the fight against the apartheid system in South Africa. The FLS diplomatic pressure against apartheid was significant and 
so were attempts to intervene militarily with limited success in Mozambique. ${ }^{30}$ The irony of intervention in countries engulfed in civil wars has been witnessed in other cases in the international system. The conflict in Bosnia- Herzegovina offers interesting observations. ${ }^{31}$ The conflict was seen and interpreted from non-traditional viewpoints of the United Nations Charter and other norms such as international law. ${ }^{32}$ From a European perspective, much has been written in the critical role played by NATO troops in the conflict in former Yugoslavia. Perhaps the best reading of the situation was provided by a declaration of Ministers of the North Atlantic Council on 12 April 1999. They declared that:

The crisis in Kosovo represents a fundamental challenge to the values of for which NATO has stood since its foundation: democracy, human rights and the rule of law... We will not allow this campaign of terror to succeed. NATO is determined to prevail. ${ }^{33}$

The comparative analysis highlighted above of the NATO involvement in Bosnia or the international legality of intervention on humanitarian grounds demonstrates the urgent need in the international system to create an enabling environment conducive to development and stability as a precursor for economic prosperity the world over. ${ }^{34}$ If NATO could claim to have contributed to peace efforts in Bosnia-Herzegovina on behalf of the United Nations, the Front Line States were arguably justified to assist a neighbouring sub-regional state to achieve peace and stability on behalf of the United Nations in the Southern African sub-region. In a way, the support offered to Mozambique by its counterparts in Southern Africa compelled the Mozambique government and Renamo to sign the Nkomati Accord in 1984 and the Rome ceasefire agreement of 1992 respectively. The Nkomati Accord was an agreement struck between South Africa and the Frelimo in which arrangement that South Africa would cease to support the MNR while Frelimo agreed to step away from supporting the African National Congress. ${ }^{35}$

After destroying the Movement of National Resistance (Resistencia Nacional Mocambicana) Headquarters (MNR) the Gorongoza military base (Casa Banana Military Base fell in 1985), Zimbabwe contributed to the subsequent peace talks between Alphonso Dhlakama's MNR and the Mozambique government in Rome in 1991 following the peacemaking intervention in that country for a period of ten years. It is important to note that the creation of the MNR was orchestrated by the Rhodesian security forces to keep in check the Frelimo government in Maputo. The apartheid regime in South Africa took over the support of the MNR after the Independence of Zimbabwe in April 1980. ${ }^{36}$ The signing of the general peace agreement resulted in the UN Security Council passing Resolution 782 on 13 October 1992 which approved the appointment by the UN Secretary-General of an interim Special Representative and the dispatch to Mozambique of a team of up to 25 military observers resulting in the subsequent deployment of United Nations Peacekeeping Operation in Mozambique (ONUMOZ) comprised of some 6000 strong by $1993 .{ }^{37}$ Several million Mozambicans were internally displaced or were rendered miserable refugees in neighbouring countries. The 13 years of the Mozambique war had wrecked much of the country's communication system and infrastructure. On the deployment of the peacekeeping 
troops in Mozambique, Zimbabwe withdrew its defense forces, thus providing an important stabilizing element that encouraged the two sides in Mozambique to come to the negotiating table.

\section{Zimbabwe Peace Support Intervention in Somalia in the Post-Cold War Era}

Again at the continental level, in 1991 Zimbabwe contributed a large contingent of its troops to Somalia. After the fall of the Siade Barre regime in Somalia there was endemic hunger strife which was compounded by ethnic cleansing by local militia gangs which made humanitarian relief efforts difficult. The Security Council passed Resolution 794 on 3 December 1992 which authorized future operations in Somalia under Chapter VII and delayed deployment of the remainder of UNOSOM. ${ }^{38}$ The United States authorities had at the same time examined the situation and concluded that major intervention with US support was required if the scale of human disaster in Somalia was to be reduced. Accordingly, the USA offered its support to the UN and the US President directed the execution of "Operation Restore Hope" on 4 December 1992. This was a combined military operation by US forces under UN auspices to secure the major seaports and airports, key installations and food distribution points in Somalia to provide free passage and security for relief supplies.

Zimbabwe initially deployed a company size (military combat size of 120 troops) contingent, which got increased to over a battalion size group over time (800 to a 1,000 combat fighting troops). Zimbabwe's role was recognized by the United Nations Headquarters by being nominated to provide a Deputy Force Commandeer to a US overall UNOSOM II Commander, Admiral Jonathan Howe. Major General Mike Nyambuya (Rtd), was appointed the Deputy Force Commander with a large compliment of senior staff officers and regimental commanders. Zimbabwean troops were tasked with, among other duties, 'guarding the northern part of Mogadishu International Airport, food distribution to starving women and children, establishing check points and road blocks in their area of responsibility, and escorting humanitarian relief vehicles'. Many Zimbabwean officers, men and women, were awarded United Nations medals for their outstanding performance on duty in the peacekeeping operations in that country.

The dynamics of the Somali conflict reached its tragic climax on 3 October 1994, when 18 American soldiers were killed and 78 wounded in a fire-fight with Somali militia which also killed between 300 and 800 Somali civilians. After this, the relationship between US Forces and Somalis in Mogadishu deteriorated further to a point where US forces had become completely estranged from the local population. The drama of United States of America soldiers dragged by Somalia bare-footed militia men in the streets of Mogadishu brought the peacekeeping exercise by the international community to an abrupt end by late march 1994 in what the Washington Post described as a "guns - cocked withdrawal" 39 . Former US President Bill Clinton unceremoniously withdrew his US troops marking the end of the UN 
Operation in peacekeeping efforts in that part of the world. ${ }^{40}$ Zimbabwe became one of the last contingents to be withdrawn from Somalia. The former American Defense Attaché, to Zimbabwe, Colonel (Dr) Dan Henk said of the Zimbabwean troops in the UN peacekeeping operation in Somalia:

Zimbabwe has undoubtedly a well-trained and disciplined Defense Force which accounted itself well in Somalia. Zimbabwe's ability to participate in peace keeping operations has become more important than has been in the recent past. ${ }^{41}$

There were reports of Zimbabwean troops assisting in the hustle and bustle of the evacuation of US troops from the marauding militia gangs after the Bill Clinton administration gave the instruction to pull US soldiers out of Somalia.

Meanwhile, while the last contingent of Zimbabwean troops was still in Mogadishu, Zimbabwe was asked by the UN Headquarters in New York to provide the UN Force Commander and a large number of UN peacekeepers in the Angolan crisis. Consequently, Zimbabwe contributed a large contingent of troops to Angola in July 1991 alongside Argentine, India, Brazil, Namibia, Romania, Uruguay, Pakistan and Zambia. In the same year Major General Phillip Valerio Sibanda, now the Zimbabwe National Army Commander was deployed in Angola to command the United Nations Peacekeeping Force in that country for a period of two years. Although the peacekeeping force in that country did not achieve its original objective due to a re-start of the civil war. Zimbabwe demonstrated its capacity to contribute to peacekeeping missions in the international system.

The Arusha peace agreement of 1994 involving the ethnic differences of the Hutu-Tutsi in Rwanda was to witness Zimbabwe sending a group of peace observers to Rwanda in that year. ${ }^{42}$ The end of colonial rule in Rwanda saw the election of president of Kayibanda, a Hutu, forming a government between 1965 and 1969 in place of the hitherto Monarch government of King Kigeri V. Meanwhile, in exile, the Tutsi refugees who had fled from persecution in the 1960s formed a rebel force in Uganda called the Rwanda Patriotic Front (RPF). In October 1990, with the support from Uganda under Yoweri Museveni, the RPF led military invasions into Rwanda agitating for political reform and the repatriation of Tutsi refugees from all neighboring states. A state of civil war then ensued in Rwanda resulting in the peace talks between the RPF and President Habiyarimana's government. Tensions continued until the 1994 genocide of the Tutsi and their moderate Hutu supporters following the "alleged" aircraft assassination of Habiyarimana.

In the Rwandan case, Zimbabwe, again, demonstrated its willingness and capacity to contribute to peacekeeping missions in the international system. During the course of the Rwanda genocide of 1994, Zimbabwe pledged to contribute fighting troops to go and protect the civilians in Kigali on condition it was given the necessary logistical support to deploy and sustain its troops in Rwanda. Regrettably, the international community especially the Western world led by the United States of America was not willing to assist in such an endeavor, especially with the bad memories of the Somalian intervention still fresh in 
their minds. The United Nations former Secretary-General, Boutros-Boutros Ghali was to condemn the inadequate and lukewarm international community's response to the Rwandan genocide when he said:

If the UN had at its disposal even a small rapidly deployable constabulary force of highly armed troops, it might have been able to prevent this new chapter in man's cruelty to man. ${ }^{43}$

At that continental level, Zimbabwe had made its mark by contributing observer teams to Rwanda following the Arusha Agreements of 1994. ${ }^{44}$ Logistical support permitting, Zimbabwe had put a company size contingent on standby to go and assist in the prevention of the genocide in Rwanda. Such gestures in the view of the writers demonstrated the country's determined commitment to peace support efforts in the international system.

Following the disastrous 1994 genocidal developments in Rwanda, Zimbabwe and South Africa went on to host successful sub-regional peacekeeping exercises by the Zimbabwe Defense Forces and the South African National Defense Forces respectively. In 1997 Zimbabwe hosted a peace support exercise code named 'Exercise Blue Hungwe' which was attended by fourteen 14) member states defense forces contingents in the eastern border town of Nyanga. ${ }^{45}$ Two years later South Africa successfully hosted a similar exercise codenamed 'Exercise Blue Crane' in the south western town of Lahathillah west of Cape Town in $1999 .{ }^{46}$

Political analysts and political commentators generally agree that the staging of such exercises demonstrated the political willingness of the Southern African leaders to achieve the desire of creating a conducive atmosphere to economic development and prosperity in the sub-region.

The launching of the two exercises symbolized the multi-dimensional character of peace support operations as enunciated by Marrack Goulding. ${ }^{47}$ Both exercises involved the active participation of non-governmental organization (NGOs), civil-organizations, humanitarian organizations and many other players including the inevitable involvement of the AU continental body representatives. The hosting of two regional peace-support operations in the sub-region, it is argued, was a testimony of the leaders' commitment to contributing to the achievement of stability and sustainable peace to facilitate economic growth and stability in the sub-region and beyond.

\section{Non-Military Agencies in Peace-Support Operations: A New Phenomenon in Peacekeeping?}

Peacekeeping has traditionally involved a primarily military model of observing ceasefires and the separation of forces after inter-state wars. Over time peacekeeping did evolve into 
a complex model of many elements - military, police and civilian working together to help to help lay the foundations of peace. There are indeed more players who are emerging in attempting to achieve sustainable peace. The adoption of the concept of new thinking in peacekeeping operations in Zimbabwe witnessed the active involvement of nonmilitary services/agencies such as the Zimbabwe Republic Police (ZRP) and the Prison Services (ZPS). Kimberly C Field and Robert M Perito in their article on new approaches to peacekeeping operations argue for a re-look involving non-military agencies in the international system. Kimberly and Perito argue that, while the military should continue to focus on security, in peacekeeping operations, civilian actors should continue to play a crucial role in achieving sustainable security.

Certainly, the international community has drawn lessons from past operations and is working to strengthen the United Nations peacekeeping capacity in a number of areas. A blueprint for reform was provided by the UN Secretary-General's Panel on Peace Operations, chaired by Ambassador Lakdar Brahimi, which issued its report in 2000. As a result of these efforts, the UN Secretary-General Ban Ki-Moon proposed, and the General Assembly approved a major restructuring of the United Nations peacekeeping apparatus, through the creation of a new Department of Field Support (DFS) ${ }^{48}$ Formally established by the General Assembly in 2007, DFS is charged with planning, deploying and sustaining UN peacekeeping missions, while the department of Peacekeeping Operations (DPKO) focuses on such matters as strategic oversight and operational political guidance. These changes were to be phased in over a period of 12 months. ${ }^{49}$

In the experience of the Bosnia crisis, in his pre-departure press conference on 17 December 2000, Bernard Kouchner, the United Nations senior official in Kosovo said, the "lesson of Kosovo was that, peacekeeping missions need to arrive with a new law-and order kit made up of trained police, judges, and prosecutors and a set of draconian security laws". ${ }^{50}$ This is the only way to stop criminal behaviour from flourishing in a post war vacuum of authority" ${ }^{51}$ Such a judicial package must be supported by effective military forces that can quickly subdue armed opposition, disarm opposing forces, perform basic constabulary tasks, and ensure that civilian law enforcement officers and administrative officials can perform their functions in an atmosphere of relative security.

Zimbabwe also demonstrated its enthusiasm in contributing to peacekeeping or peacesupport in other areas outside the military. Zimbabwe contributed some civilian police units in the Bosnia Herzegovina conflict in Europe under the auspices of the United Nations. Earlier, the Zimbabwe Republic Police (ZRP) had been involved in UN peacekeeping operations since 1991. They were deployed to Angola as part of the UN Verification Mission (UNVM) following the withdrawal of Cuban troops from Angola. The main task of UNVM was to verify the implementation of the cease-fire agreement and the neutrality of the Angolan police in line with the peace accord. In 1993, the ZRP sent five police officers to Somalia on UN duties to assist in training of a Somali Police Force. 
The United Nations has continued to recognize the professionalism of the Zimbabwe Republic Police by offering them demanding field appointments in the international arena. In July 2007, Assistant Commissioner Crowd Chirenje who was based in Addis Ababa took up the post of Planning Officer assisting the African Union Mission in Somalia (AMISON) in planning and mobilization of recoveries for the Police component of AMISON. Assistant Commissioner Apolonia Munzwerengi served as the Vulnerable Persons Coordinator in East Timor for three years after serving as a peacekeeper in the same country for one year.

Assistant Commissioner Charity Charamba was appointed Operations Coordinator in the UN Mission in Liberia (UNMIL) in 2009. United Nations continues to request for more Zimbabwean officers to undertake peacekeeping mission in different parts of the world in recognition of their professionalism and competence. The ZRP also had the experience of working with the European Union forces in Kosovo. The Commissioner General of the Zimbabwe Republic Police, Commissioner Augustine Chihuri while briefing returning police officers from peacekeeping operations in Kosovo said, "we are now only sending our police officers for peacekeeping duties in East Timor and Liberia, where there is still need." ${ }^{52}$

Senior Zimbabwe Police Officers continued to receive world recognition by being appointed to top United Nations positions in Africa and Asia. Since May 2006 a Senior Assistant Commissioner and three Assistant Commissioners have been appointed to head UN missions in Africa and Asia. Commissioner Chihuri went further to say that, "ZRP officers continue to receive recognition from the UN through direct appointment by the world body besides the usual participation by the many officers in peacekeeping missions around the world. 53" Senior Assistant Commissioner Clement Munoriarwa was the first to be appointed as Mission Planning Coordinator for the UN for the Mission in Khartoum Sudan. ${ }^{54}$

Over and above the experience of the Zimbabwe Defense Forces (ZDF) and the Zimbabwe Republic Police (ZRP), the Zimbabwe Prison and Correctional Service (ZPCS) has been actively involved in peace-support operations as well. In the Sudan peacekeeping mission, the ZPCS deployed three officers to Khartoum in April 2009. The three officers were Chief Superintendent Taurai Rugara, a medical doctor, Superintendent Granisa Musango and Superintendent Ruzvidzo Muchingwe who are engineers. The officers were charged with the responsibility of providing advice and support to Sudan's prison services personnel, developing local training capacity and providing training to personnel at senior management and institutional levels. ${ }^{55}$

Two other officers were deployed to Liberia to assist in the development of local capacity at senior level. Of note is also the improvement of gender balance in these peacekeeping missions. The deployment of Deputy Commissioner Fadzai Mupure and Superintendent Granisia Musango demonstrates Zimbabwe's efforts to improving United Nations' gender balance in international peacekeeping missions. 
As of January 2013, large numbers of the Zimbabwe Republic Police officers continue to be deployed in Sierra Leone as mentors where they are providing a training programme for the Sierra Leone Police Force. Further afield, the Zimbabwe Republic Police deployed over 260 police officers to UN peacekeeping in East Timor among other countries in the international system. Among some of the duties the Zimbabwean contingent has been performing in these countries was to support humanitarian assistance, monitor and advise on the implementation of agreements, and the training of local law enforcement agents.

\section{Conclusion}

In conclusion, it has been argued that the active participation by Zimbabwe in the numerous efforts on peace support operations cited in the discussion is testimony of the country's desire to contribute towards peace and security activities in the international system. Through that experience the country gained experience in the exercise of peacekeeping in the sub region and abroad including Angola, Mozambique, Rwanda and Angola. It has been argued that, in regional terms Zimbabwe played an active part in peace efforts in Mozambique prior to the arrival of the UN Monitoring Force between the Frelimo Government and the MNR in early 1986. Indeed military operations in Mozambique by the Zimbabwe Defense Forces under the umbrella of the Front Line States had its own setbacks in its implementation, especially in general economic terms where Zimbabwe's economy got a shattering effect for long time after the end of the conflict. But many political analysts argue that Zimbabwe took a noble cause by coercing the RENAMO rebels to the negotiating table and in the process contributing in the resolution of conflict in that country.

To enhance its capability and incorporate other non-military actors in the exercise of peacekeeping, Zimbabwe and South Africa undertook two peacekeeping exercises 'Exercise Blue Hungwe' in Zimbabwe and 'Exercise Blue Crane' in 1997 and 1999 respectively. Finances permitting, the launch of peacekeeping training exercises could be a welcome development in the noble cause of carrying out peacekeeping operations in close collaboration with the African Union and the Security Council at the United Nations.

Zimbabwe contributed a large contingent of United Nations Peacekeepers and Observers including the UN Commander of UNVEM1 and II in Angola from 1991 to 1994. In that campaign Zimbabwe troops assisted in the monitoring of the ceasefire, the verification of the demobilization of combatants leading to the elections in 1992. When the elections of 1992 were rejected by the National Union for the Total Independence of Angola (UNITA), the country again plunged into war till 1997.

Finally, it has been argued that Zimbabwe has contributed in the discourse of the emerging new thinking in peace support operations. Peacekeeping operations are likely to remain complex and at times sensitive to resolve by merely conventional peacekeeping wisdom. The continued deployment of non-military actors in peacekeeping missions the world over 
is likely to yield positive results by empowering disadvantaged communities to develop their appropriate capacities to reduce political tension and violence within and between states in the international system.

\section{End Notes}

1 Bowet, D. W. (1964). United Nations force: A legal study of the United Nations practice. London: Steven and Sons, p. 25.

2 Charter of the United Nations and Statute of the International Court of Justice; Department of Public Information, United Nations New York, 2003.

3 The Basic Facts about the United Nations. United Nations Department of Public Information, New York, 2004, p. 73.

4 Marrack Goulding, Peace Monger, John Murray, London, 2002, p. 15.

5 The United Nations Today. United Nations Department of Public Information, New York, 2007, p. 82 .

6 Ibid; p. 76. World leaders gathered for the 2005 World Summit adopted the responsibility to protect which entailed the prevention of such crimes, including their incitement, through appropriate and necessary means. The United Nations also strengthened its resolve by establishing the Human Rights Council in 2006 as a subsidiary organ of the General Assembly.

7 Ibid.

8 Joshua, G., \& Jon, C. P. (2013). International Relations (10th ed.) Pearson: United States, p. 248.

9 Boutros-Ghali Boutros. (1992). An agenda for peace: Preventive diplomacy, peacemaking and peacekeeping. New York: United Nations Information Publishers.

${ }^{10}$ Joshua, G., \& Jon, C. P. International relations Op Cit; p. 249.

${ }^{11}$ Ibid.

${ }^{12}$ Ibid.

${ }^{13}$ The British Army Manual 1994 (3rd ed.). London: Wider Peacekeeping.

${ }^{14}$ Ibid.

15 The Chapter of the United Nations and the Statute of the International Court of Justice. (1997). New York: The United Nations Department of Public Information. 
${ }^{16}$ Joshua, G., \& Jon, C. P. (2013). International relations (10th ed.). United States: Pearson. p. 249.

${ }^{17}$ The Communiqué of the Heads of Government and State in Durban, South Africa, 2002.

${ }^{18}$ Ibid.

${ }^{19}$ The Communiqué of the G8 Leaders at Kananakis, Canada 2002. At the Group of Eight (G8) leaders adopted the Action Plan (AAP) with a unanimous agreement to support Africa in its endeavours of achieving the objectives of NEPAD.

${ }^{20}$ African Chiefs of Staff Meeting on 15 May 2003 in Maputo, Mozambique, 2003. The Peace and Security Council was eventually launched in Addis Ababa by the Heads of States and Government in May 2004.

${ }^{21}$ Paul, M. (1982). The struggle for Zimbabwe from 1965 to 2000. London: Steven and Murray, p. 67.

${ }^{22}$ David, M., \& Johnson, P. (1981). The struggle for Zimbabwe. Harare: Zimbabwe Publishing House, p.70.

${ }^{23}$ Ibid: p. 185. The 1979 Lancaster House Constitutional Talk's primary objective was to end the war and to strike an amicable compromise between the liberation fighters and the white minority setters. The Constitution arrived at from this conference entrenched the minority rights over the issue of land. The British white setters represented by the 'White Rhodesians' in their hubris and belief in their 'divine superiority' were are aware of the likely impact of the United Nations.

${ }^{24}$ Knox Chitiyo and Martin Rupiya “Tracking Zimbabwe Defence Forces from 1980 - 2005, edited by Martin Rupiya Evolutions and Revolutions for a detail on the historical overview of the UDI on 11 Nov 1965 by Ian Douglas Smith.

${ }^{25}$ Ibid: The Ceasefire Agreement reached at Lancaster House was noted monitored by the United Nations despite concerted efforts by Robert Mugabe and Joshua Nkomo to involve the United Nations in the settlement of the Rhodesian dispute.

${ }^{26}$ J H B Auckland, The Rhodesian Operation, The Guards Magazine Journal of Household Division, Summer, 1980,p. 46. Note should however be taken that some of the peacekeeping experiences the country went through were not United Nations driven (even though there was indirect UN sanctioning) like the Commonwealth operation in 1979-80. In Mozambique there was more of enforcement than peacekeeping. Furthermore, the thrust was the Cold War era because there was need to distinguish the peacekeeping scenarios during and after Cold War era because of different emphasis. In the intervention in Mozambique and including the resolution of the Crisis at the Rome Accords and the set-up of ONUMOZ were shaped by Cold War dynamics including Zimbabwe's participation in peacekeeping in Angola (UNAVEM I, II, \& III). On the other hand Zimbabwe's peacekeeping duties in Somalia (UNISOM) and to a limited extent in Kosovo, Liberia as well as peace-building in Liberia were to a large extent driven by changing norms in the post-Cold War era such as humanitarian intervention. 
${ }^{27}$ Basic Facts about the United Nations, United Nations Department of Public Information, New York, 2004, p. 72

${ }^{28}$ David, M., \& Johnson, P. (1981). The struggle for Zimbabwe. Harare: Zimbabwe Publishing House, p. 129.

${ }^{29}$ Deon, G., \& W Gutterridge. (1983). The Constellation of Southern Africa : South African States and SADCCC: Toward a New Regional Stalemate, Pretoria, Transfontein Press. Also see, The destabilization report, edited by David Martin, 1985.

${ }^{30}$ Robert, J. (1983). A regional role for Africa's Front Line States: Experience and prospects. Adelphi Paper No 180, London.

${ }^{31}$ Note should also be taken on the draw parallels between the NATO intervention in Kosovo and the 'SADC' intervention in the DRC- after all both missions were not UN sanctioned peace enforcement missions. On one hand, the NATO mission was grounded in the 'illegal but legitimate' principle based on the new norm of humanitarian intervention which argues that sometimes humanitarian concerns overrides international principles of sovereignty and territorial integrity. On the other hand, the SADC Mission was in defense of the traditional principle of absolute 'sovereignty and nonviolability of territorial integrity' debate.

32 The United Nations Charter and Statute of the International Court of Justice, United Nations Information Department, New York, 2006. Also see, L Weirs, Lessons from Bosnia, Washington DC, National Defense Press, 1998.

33 Jane M O Sharp. (1993). Bankrupt in the Balkans: British policy in Bosnia. London: Institute for Public Research Publications, p. 213.

${ }^{34}$ On the detail of changes in the Law of Humanitarian Intervention, see Christopher, G. (1993. February 2). Is there a right of humanitarian intervention? The World Today, 49(2).

${ }^{35}$ Taisier M Alii, \& Robert O. M. (2007). Civil wars in Africa, roots and resolution. London: McGillQueen's University Press, p. 133.

${ }^{36}$ Deon, G., \& Venter, D. (1984). Destabilization controversy in Southern Africa. South Africa Forum Position Paper.

37 The United Nations Resolution 782, 13 September, 1992.

38 The United Nations Resolution 794, 3 December, 1992

39 The Washington Post. (1993, December 8). US to leave Somalia with its Guard Up.

40 The withdrawal of United States of America troops in October 1993 was quickly followed by similar announcements by the developed countries including Australia, Belgium, Canada, Ireland, Italy, New Zealand, Norway, Turkey and Sweden. 
${ }^{41}$ The Herald. (1993, September 15). Also see D Henk. (1996, January). Peacekeeping: Perils and Prospects, The Ten Lessons Learned from Recent Operations in Somalia. Paper presented at a Peacekeeping Symposia, Pretoria, RSA,

42 The Herald. (1994, September 7).

43 The United Nations Commission Report on the Genocide in Rwanda. (1995). In response to the UN Commission on the Rwanda genocide by the United Nations Headquarters in New York, the Secretary General blamed the lack of the international community in responding to the requests of the Canadian United Nations Force Commander General Delaire to reinforce the UN troops in Kigali. In that incident, instead of reinforcing the UN troops, the force level was reduced to some 320 at the outbreak of the genocide.

${ }^{44}$ Interview with Major General Edzai Chimonyo (Chief of Staff Operations and Plans) at Ministry of Defence and Defence Forces Headquarters with the author, Harare. 2000. Zimbabwe deployed a small contingent of 11 Military Officers under the auspices of the African Union to monitor the implementation of the Arusha Accord six months before the outbreak of the genocide.

${ }^{45}$ Exercise Blue Hungwe, Zimbabwe Government Publishers, Harare, 1997. The Peacekeeping training exercise was attended by fourteen Southern Africa Development Community member states in the eastern town of Nyanga in Zimbabwe.

${ }^{46}$ Exercise Blue Crane, South Africa National Defense Force, Government Printers, Pretoria, 199. The Peacekeeping training exercise was also attended by fourteen Southern Africa Development Community member states including representatives of the International Red Cross Community (ICRC) in the western town of Lahatlha in South Africa.

${ }^{47}$ Marrack Goulding, Peace Monger, op. cit; p. 72

48 The United Nations Today. (2006).United Nations Department of Information, New York.

${ }^{49}$ Ibid.

${ }^{50}$ Kimberly, C. F., \& Robert, M. P. (2003). Creating a force for peace operation: Ensuring stability with justice in Parameters. Washington: The Us War College Publication, XXXII(4), 78.

${ }^{51}$ R Jeffrey Smith. (2000, December 18). Kosovo still seethes as UN official nears exit. The Washington Post.

${ }^{52}$ The Herald. (2009, April 21).

${ }^{53}$ Ibid.

${ }^{54}$ Ibid.

55 The Herald. (2009, April 27). 


\section{References}

Ali T. M., \& Matthews R. O. (2007). Civil Wars in Africa, Roots and Resolution. London: McGill-Queen's University Press.

Auckland, J. H. B. (1980). The Rhodesian operation. The Guards Magazine Journal of Household Division, Summer.

Bowet, D. W. (2004). Basic facts about the United Nations Department of Public Information, New York.

Charter of the United Nations and Statute of the International Court of Justice. (1997). United Nations Department of Public Information, New York

Communiqué African Chiefs of Staff Meeting on 2003 May 15 in Maputo, Mozambique.

Communiqué of the G8 Leaders at Kananakis, Canada. (2002).

Communiqué of the Heads of Government and States Meeting in Durban, South Africa. (2002).

Exercise Blue Hungwe Government Printers, Harare, 1997.

Geldenhuys, D., \& Gutterridge, W. (1983). The constellation of Southern Africa: South African States and SADCCC: Toward a new regional stalemate. Pretoria: Transfontein Press.

Geldenhuys, D., \& Venter, D. (1984). Destabilization controversy in Southern Africa. South Africa Forum Position Paper.

Goulding, M. (2002). Peace Monger. London: John Murray.

Kimberly, C. F., \& Robert, M. P. (2003). Creating a Force for Peace Operations; Ensuring Stability with Justice. Washington: Parameters the US War College Publication, $X X X I I(4)$,

Knox, C., \& Martin, R. (2005). Tracking Zimbabwe Defence Forces from 1980 - 2005. In Martin Rupiya (Ed.). Evolutions and revolutions: A contemporary history of militaries in Southern Africa (p. 347). Pretoria: Institute for Security Studies.

Martin, D., \& Johnson, P. (1981). The struggle for Zimbabwe. Harare: Zimbabwe Publishing House.

Martin. D. (Ed.). (1985). The Destabilization Report. 
Moorecraft, P. (1982). The struggle for Zimbabwe from 1965 to 2000. London: Steven and Murray.

R Jeffrey Smith. (2000, December 18). Kosovo still seethes as UN official nears exit. The Washington Post.

Robert, J. (1983). A regional role for Africa's front line states: Experience and prospects. Adelphi Paper No 180, London.

Martin, R., \& Chitiyo, K. (2005). Evolutions and revolutions: A contemporary history of militaries in Southern Africa. Pretoria: Institute for Security Studies.

Sharp Jane, M. O. (1993). Bankrupt in the Balkans: British policy in Bosnia. Institute for Public Research Publications, London.

The Basic Facts about the United Nations Department of Public Information, New York.

The British Army Manual (3rd ed.) (1994). Wider Peacekeeping, London.

The Herald. (1993, September 15).

The Herald. (1994, September 7).

The United Nations Resolution 782. (1992, September 13).

The United Nations Resolution 794. (1992, December 3).

The Washington Post. (1993, December 8).

United Nations Commission Report on the Genocide in Rwanda. 1995. 